\title{
Socio-Cultural Study of Village Deities in Peraiyur Taluk of Madurai District with Special Reference to Hero Stones
}

\section{S Anandakumar}

Madurai Kamraj University, Tamil Nadu, India

Corresponding author: anandsaduragiri7@gmail.com

Received: 10-04-2019

Revised: 15-07-2019

Accepted: 17-08-2019

\begin{abstract}
For as long as man has been on earth he wonders who he is where he comes from and why he acts the way he does. It would seem that much of human history has resulted from mans efforts to answer these questioning, because of the limits of his knowledge and technology, man throughout most of his history, has been unable to date concerning his own behavior and background. Hence, the has relied bodies of myth and folklore to answer these questions. Anthropology, as it has emerged over the last two hundred years is the scientific approach to answering mans questions about him. Even the early Anthropologists were led by their research to a realization of the social functional of religion. The study of totemic is points up this tendency. Thomism is based on the division of the whole world into those thing which are profane, or have no spirit was value for the Elam or tribe and these which are sacred. Not only gods spirits and sacred indeed, according to sociologist Emile Durkheim a rock, a spring, a pebble, a piece of wood, a house, in a world anything can be sacred.
\end{abstract}

Keywords: Knowledge, technology, anthropology, religion, Elam or tribe, Emile Durkheim

The Indus people worshipped nature. They worshipped the pipal tree. Some of the terracotta figures appear to be mother goddess. Fire altars have been identified at Kalibangan. They buried the dead. Burials were made elaborately and evidence of cremation is also reported. The Harappan burials have pottery, ornaments, jewellery, copper mirrors and beads. An interesting find is of a possible Temple, indicated by a block of sandstone surrounded by a rubble circle, similar to the contemporary Temples. Found at Baghor in Uttar Pradesh, it is the earliest known evidence of a Temple in India. These suggest their belief in an afterlife. The burial system followed by the people of Neolithic period continued into the Megalithic period. A circular tomb using big stone slabs built upon the place of burial is known as a megalith. Such megaliths have been found in many parts of Tamil Nadu. The urn burial system was another type of practice and is evidenced in Adichanallur, Kodumalal, Arikamedu, and Paiyampalli. Black-ware is peculiar to burial sites in Tamil Nadu.

Interestingly, black-ware is found mostly in burial mounds and not in human habitations. In a majority of urn burials, the use of stone is almost non-existent. However, urn burials are grouped under megalithic because the materials - the pottery, iron objects, beads of semi-precious stones kept in them - are identical to those found in the stone burials. The end of Megalithic burial practice is assigned to third-second centuries CE. During this period Brahmi writing akin to Ashokan Brahmi has been discovered in Kodumanal (Erode District). There is also evidence of the megalithic tradition continuing into later centuries. During the Sangam period people 
still remembered urn burials. The four primitive herostones with Tamil Brahmi inscriptions, datable to third to second centuries BCE found in the upper part of the Vaigai valley, support the authenticity of the hero stone tradition described in the Sangam Tamil literature in the context of cattle raids. Scholars infer, based on such evidence, that the some of the Sangam poems could be assigned to the early first century BCE or a little earlier.

The tradition of erecting hero stones in memory of dead warrior-heroes is considered to be an extension of the menhir type of megalithic tradition. Menhirs, upright monumental stones, and dolmens made of big slabs or boulders are megalithic tombs found in Tamil Nadu. Black and red ware, along with partial human remains and iron objects, were unearthed recently at Vadamalkunda in Krishnagiri, Tamilnadu. A few stone slabs were also found at the site. A centuries-old menhir at Singaripalayam excavated near Kundadam in Tiruppur district points to the existence of an ancient settlement along the banks of River Uppar. Adichanallur, $22 \mathrm{~km}$ from Tirunelveli, is located in Thoothukudi district. In 1876, a German ethnologist and naturalist, Andrew Jagor conducted an excavation at Adichanallur.

During the Later Vedic period the upper Ganga Doab was the centre of the Aryan culture. This region is described as the land of Kuru-Panchalas. The Vedic gods Agni and Indra lost their importance. Prajapati became the main deity. Rudra, the god of rituals and identified with Siva, became important. The Satapatha Brahmana lists the names of Rudra as Pasunampatih, Sarva, Bhava and Bahikas. Vishnu was conceived as the protector of people. There is no reference to Vishnu's incarnations. Each varna had its own deities. Rituals became important in society. It was believed that rituals and sacrifices could solve many problems. The rituals became more complex, required more resources, and took longer time. This indirectly reflects the demand for rituals of the formation and elite groups who could spend more resources on rituals and sacrifices.

\section{Backdrop of the Study}

The Village deities are patron deities or grama devata of village. They are found in almost all villages throughout India most of the deities in Tamil Nadu and particularly Madurai district. India experienced an early development of cultures and civilizations. They are known as Kaval deivam or guardian spirits of Local Village Gods. They are associated to a main deity who is generally ascribed as Kuladeivam by various sects of community and tribe groups as part of the tracing their generation through centuries. The worship of the village god and goddess is the most ancient form of Indian religion. Temples are an entire part of the social cultural mosaic of India. As an institution they do not only have significance in the field of religion but also contribute significantly to the furtherance of education, literature, music, dance, art and architecture. The temple is so deeply ingrained in the psyche of Indians, particularly south Indians. The ancients advocated that one should not take up residence in a place where, there was no temple.

\section{"Koil illadha ooril kudi irukka vendam"}

Do not live in a place where there is no temple.

"Alayam thozhuvoohu saalavum nandru"

To offer worship in a temple is highly beneficialAvvaiyar in Kondraivendan. The temple culture of India in general and south India in particular is a part of life of the people. The temple played a significant role in their external as well as internal development in the cultural life of the people. The development of village Gods is the worship of hero's who laid down their lives for the causation of their caste or community. These heroes were commemorated and worshipped by the erection of Hero Ston's or Memorial Ston's, thousands of which are found in Tamil Nadu and other parts of India. The erection of Hero Ston's and the respect of the dead hero's as the saviors spirit of the community may be considered as an extension of the prehistoric cult of erecting megalithic tombs. The Hero-Stones are in the form of a dolmen with three upright slabs erected in the form of a small chamber and topped by a hat stone. The figure of the hero is carved on the back slab, facing the front. The representation of the hero on the slab takes various forms. The simple shows him in the act of fighting with a spear, a sword, or bow and arrow.

The origin of folk deities is well prevalent in the villages 
of Peraiyur Ttaluk. Their origin but also the miracles made by these deities in their ancient glory and quantum of faith they had on them all fold.

The mode of worship and the rituals are changing day by day and village to village. The beliefs and sentiments regarding various deities in Peraiyur region are widely prevalent among the common people. Deities like Ayyanar, Mathuraiveeran, Pandimuni, Muneeshwaran, are come under male category. Muthalamman, Panchaiamman, Kannimar, Ochchandammal, Pachchiamman, Muthunayakiammal etc., Peraiyur Durgai Amman, S. Keelapatti Kaliamman, Chellaiamman, Devaniyapuram Ayyanar, Thummanayakanpatti Mariyamman, Perungamanallur Karuppu Kovil, Sankilikaruppu, Elumalai Vasimalaiyan, Sadaiyandi Kovil, Muthalamman, Badrakali, Hero stones, Uthappuram Niraikulathu Aiyanar, Paraipatti Karuppasamy. E.Kottaipatti Pethanasamy Kovil, Muthaiah Kovil, Tirumanikkam Hero stones, Pregnant women worship, Aiyanar Kovil, Periya Meenakshipuram Aiyyanar Koil, Athikaripatti Muppitarriamman, Vannankulam Paripur anaswamy kovil, T.Perumalpatti Vellaiammal Memorial Stone, Pillamanayakar Samy, Saptur Muneeswarar, Kottaikaruppusawamy, Melappatti Veeruchinnammal are the female deities under worship by people of the village of the Peraiyur Taluk.

\section{Aim of the Study}

This study aims to trace out the origin and history of every Village deities and hero stones around Peraiyur taluk in Madurai district. The particular caste or community behind a particular deity and their pattern of worship etc., are to be studied. The impact of worship of village deities in this region would be traced. The iconographic details of the folk gods and goddesses are also to be studied and their connection if any with the Vedic gods are also to be carefully analyzed. Mode of their worship festival and ceremonies are to be discussed.

\section{METHODOLOGY}

The present study has been constructed by using the analytical, critical and interpretative study methods. Both primary and secondary sources will be utilized to frame the study. Mainly descriptive methodology is to be adapted for study. Comparative study is necessary among different area and to comparative approach to be taken. Statistical study is also adapted if necessary.

\section{Sources}

Both primary and secondary sources are used for the present study the study work entitled village deities under the Madurai Nayaks: Its myth and ceremony and festival. The data is collected from the field survey is called as a primary sources. Therefore the researcher went to male and female temple folk deity temple directly in the Madurai district for collecting information from the temple priest temple administration and the worshipers. The rest of the printed materials such as previous research papers, Books such as D. Hendry white heard's works on The village Gods of South India (1921) explains the definition of worship in a brief manner. K. Rajan's work on South Indian Memorial stone (2000) Mentioned about the memorial stone worship in the Tamil country. A. Mahalingam's works on Vijayanagar Nayaks Art and culture (2012) trace out the political back ground of Nayaks dynasty. A. Ramanathan's works in Tamil Tamilar Vazhipanpadu Marapukal (2006) mentioned about the worship pattern of folk deities in Tamil country. S. Sanmugasundaram \& Bala Subramaniyam. R Natupura Theivankal, (1999) mentioned about the fair and festivals in Tamil country.

\section{CONCLUSION}

I concluded that the village gods and goddess worshiped the important village deities of Tamil Nadu. The magnificent temples of Tamil Nadu are mostly Siva and Vishnu temples. There is another category of gods and goddesses whose temples are predominant in the villages. These are the village deities called as Grama Devata and their temples may be seen in every Tamil Nadu village and town. The Grama Devata is periodically worshiped and propitiated. Village people fear the wrath of these deities but generally they are benevolent divine beings. The villages are essentially farming communities and so the Tamil Nadu countryside is dotted with shrines to these gods. The village deities are the guardians, the healers and the ever present help that every little village and town has. They have a major role to play in the day to day life of the people and protect 
them from the countless ills, afflictions and pains of everyday village life. These gods are called as Ayyanar, Muniappan, Mariamman, Angalamman, Pidari, Karuppana swamy, Periasami and so on. Mariamma is the commonest of them all. Her function is to bring rain and ward off and cure small pox, chicken pox, measles and rashes.

\section{REFERENCES}

Devakunjari, D. 1978. Madurai Through The Age, From the Earliest Times to 1801. A.D, Society for Archaeological Historical Research, Madurai.

Gabriele Dietrich, 1977. Religion and Peoples organization in east Thanjavur; Christian literature society, Madras, pp. 126.
Pate, H.R. 1917. Gazetter of Tirunelveli, Tamil Nadu.

Manohar M.D. 2009. Dalits and Religion (ed.) Atlantic, publishers and distributors Private limited, New Delhi.

Amirthalingam, M. 2012. Sacred groves of Tamil Nadu and their management, Forestry Extension Division, Department of Forest, Government of Tamil Nadu, Chennai.

Romila Thapar. 1984. From Lineage to State: Social Formations in mid First Millennium BC in the Ganga Valley. Oxford University Press.

Sharma, R.S. 2005. India's Ancient Past. Oxford University Press. 